\title{
Venetians in Arberia and the Role of Venetian Language in Everyday Communication
}

\author{
Irena Ndreu \\ Faculty of Foreign Languages, \\ University of Tirana
}

Doi:10.5901/ajis.2017.v6n1p125

Abstact

This paper aims at presenting a comprehensive overview of Venetian Albanians and the interplay of Venetian language in their everyday communication. In the everyday relations between authorities and the inhabitants of this province, language became a barrier to understanding at a basic level. The local Roman language spoken over e long period of time in Arbëria was slowly substituted by the Venetian dialect. Patricians had knowledge of it before the Venetian period, since otherwise they would haveb had to rely on translators or soldiers and common clerks who were bilingual. Other language problems Venetians faced with language concerned Serbian in translation offices, a language widely used in Arbëria. It is most likely that there was such an office in Shkodra where in 1409, Ginus Juban, aka Gjin Jubani, appears as a translator. Although he bears a typical Arbër name, it cannot absolutely be stated what his official language was. The superiority of the Venetian language in the judicial and commercial areas had an effect in the Arbëria language as well. Serbian, which had played an important role under the Balshajs among bishops as their official language, became exctinct with the fall of these states. Greek was marginalized from Durrës to further south, where there were found islands of Greek settlements around the city of Vlora.

The Archbishop of Tivar Ëilhelm Adae (1332) wrote that Tivari, Ulqini, Svaçi, Shkodra, Drishti were inhabited only by Latin people, but Venetians distinguish here between the Latin and Albanians (1404). The local Roman language was substituted among them by the Venetian dialect, which the patricians knew before the Venetian period. In addition, the Albanian element had penetrated here in the caste of ruling noble families, as has been demonstrated to us by the names of Albanian families and clans like Malliocus, Maliocus (1376 Albanian - malok). Shkodra, apparently, was Albanized completely in XIV; with the onset of the Venetian rule (1399), the bookkeper (latin comes) was obliged to get a translator because he could not understand the language 1 .

In the everyday realtions between authors and inhabitants of the province, language became a problem in understanding at the basic level. As a rule, the Venetian authorities did not recognize the local language and did not learn it either before they arrived or during their stay in Arberia. Since after their service they could be sent to Italy, Greece, Crimea or Egypt, they could not learn the respective languages. It was only a few Venetian aristocrats who had such a good mastery of the Balkan languages that they could communicate easily with the local people. They must have communicated easily in the cities with the remaining Roman populations. On the contrary, they would have had to rely on translators or soldiers, or clerks of the lower level who were bilingual. Venetians also faced issues with the language of Serbian missions, which were spread throughout Arberia. Since Balsha and Serbian bishops, these powerful neighbors, used in their documents the Slavic language, Venetian authorities were obliged to translate all the texts in Latin or Venetian. Most likely, there was one such translation mission in Shkodra. In Shkodra, one finds in 1409, Ginus Juban, aka Gjin Jubani as a translator; although he bears a typically Arber name, it cannot be stated ultimately what language he operated in. The same uncertainty characterizes the case of Dobrosani from Shkodra (1458). It is different, however, with Stefan Sabini, who as an "arbër translator" definitely used the Arber language (1459)2. 
It can clearly be stated that the warfare of the time period was not favorable for the development of cultural life in the Arber area. The conditions for embracing humanist ideas, which had pervaded the 15th century Dalmatia, especially the region of Ragusa, were widely lacking in Venetian Arberia: they were missing an educated lay class which made a living from trade with the far-away countries; for material reasons, the municipalities did not hire intelectual Italians to serve them, Italians of the rank of Philippus de Diversis, who could make the description of the cities in energetic human Latin; what they were lacking were not only financial means, but also a laymen environment with literary interests, like they had then in Ragusa. In these conditions, under economic and political hardships, it was impossible to experience a bloom of remarkable spiritual life in the Venetian province. Neither the tradesmen nor the authorities and soldiers of Venice cound give the lay Arber society any remarkable spiritual life. The key "intelectual" life positions, those of notaries and secretaries in missions, were held in most cases by Italians. The consequesnces of this were that Latin and Italian in Venice marginalized the old languages in the missions, Serbian and Greek, and - as the statute books in Shkodra demonstrate - they also overlapped the dalmatian dialect of the cities. The "Romanization" of written documents under the Venetian rule can be observed in the documents preserved by the Shkodra mission as well as by the dissappearance of the old Slavic mission in Shkodra with the death of Thomas Sclavo, the offcial and owner of great influence (1429) 3 . The superiority of Venetian in the judicial and commercial life had an impact in the role it played with the Arberesh language. Serbian, which had played an important role under the Balashaj-s among the bishops as the language of documents, dissapeared with the fall of these states; Greek was marginalized from Durres further south, around Vlora in the Greek settlements. Never before had the language of missions in Middle and Norther Arberia had such a unified Roman character as it did under the Venetian rule. This resulted in cities being connected strongly in the mediterranian circle through trade. Venetian citizens in Arberia felt that they belonged to the Adriatic cultural space, and so did the citizens of Dalmatian towns.

\section{Debizantinizzazione}

The "debyzantinizing" of Arberia had reached its climax in the second half of the 15th century. However, it was not followed by any "Arberization" of the written language. With the only exception of a small attempt by the archbishop Father Pal Enjgjëlli, who recorded in 1462 a baptism formula in Arberesh language, this language was not used in its written form ${ }^{4}$. The Venetian rule instead brought the popularity and solidification of the Roman element. These cultural influences, however, only affected the slight layer of those who could write. As far as the other uneducated group and the language they used and the way they thought, almost nothing can be stated with certainty.

The lack of intelectual activity among the layman cannot, however, be used as an argument that the cultural change in Arberia did not affect Venetian inhabitants. Humanists of Arberesh descent like the famous astronaut and one of Scanderbeg's most trusted men Gjon Gazulli (aka Johanes Gasulus), could not find the necessary material and intelectual conditions, that is why they immigrated. Gazulli had a career in rich Ragusa ${ }^{5}$. Before him, numerour religious men had immigrated to Dalmatia and Italy. This brain drain was caused in essence by the numerous wars in the Arberesh area and by the uncertainty they brought, as well as the frequent stagnations of economic life. It was not talents that were missing in Arberia during Venetian times, it was the general favorable conditions.

Life in the center of the catholic church developed differently. The Arber clergymen relations with Italy had been stiff for a long time and higher clergymen like Pal Engjëlli and Gjergj Pelini knew the Apenin Peninsula well from their frequent trips, which brought them in contact with the humanist movement. Clergymen were in demand in remote municipalities, like Drisht, for their reading and grammar abilities ${ }^{6}$. Through the church, especially through the Archbishop Residency of Durres, Middle Arberia saw the renaissance thought in the second half of the 15th century. Scanderbeg recounts in a document how he had been told about the Epirotan origin of his people. The Archbishop Father Pal Engjelli showed an even higher interest, who most likely, had an impact in the historic consciousness of prince Kastriot. Pal Enjelli, a proud man for the stratification of nobility, spread the myth of his family's relations with the Byzantine empire dynasty of Angles, a legend which the archbishop's descendants migrating in Italy used to decorate themselves. Engjelli was especially interested in prince families originally from Byzant or Serbian, who had once ruled in the Arber area. He

${ }^{3}$ Të dhënat për dokumentet e ruajtura gjenden në SAINT - GUILLAIN, te SCHMITT, Actes 299-307.

4 ELISE, History $134 \mathrm{v}$.

${ }^{5}$ ELISE, History I 27-31.

${ }^{6}$ NOVAK-SUFFLAI 20. 
used for this, as his friends and peers also did, slavic forms for the names. In this spirit, he called the Topia-s in their "Karloviçi" name; he called himself Johan Balsha before the senate "Ivan Balsic or Stezh"7. These slavic first names demonstrate how around 1465, in Drisht and other generous areas, in such a Catholic and antiserbian place, there were still remnants of the Serbian cultural influence from the royal times ${ }^{8}$.

The only two historic works from the pen of inhabitants of the Arber area came out at the beginning of the 16th century in the Italian migration. It is almost certain that the nobleman Johan Muzaki, and the priest from Shkodra Marinus Barletius, author of a family chronicle a biography of Scanderbeg and a history on the seige of Shkodra (1478), had been deeply influenced by Father Pal Engjëlli and other members of his kin. The Angles played an important role during and after the Venetian rule, in creating a historic overview of Arberia, and in their center the immense figure of Scanderbeg and the diverse layer of the high society.

The cultural proliferation of the circle of Angles in their settlement in Venice - let's remember only the many translations of the work of Barleti, which determined the image of Scanderbeg in the West - should not create on us any illusiom that as a great and talented Latin user Barleti, as well as Johan Muzaki, who narrates in a very good Italian, their works were not written in their country but in Italy.

\section{References}

Milan Shuflai Qytetet dhe kështjellat e Shqipërisë, kryesisht në mesjetë, Onufri 2009, fq. 77. Oliver.J. Schmitt , Das venezianische Albanien 1392-1479, Munchen: Oldenbourg 2001, f. 403. SCHMITT, Actes Nr 68 "Juani Balsich alias Stexi". 